\title{
From the Waters to the Plate to the Latrine: Fish and Seafood from the Cardo V Sewer, Herculaneum
}

\author{
Rebecca Nicholson $^{1} \cdot$ Jennifer Robinson ${ }^{2} \cdot$ Mark Robinson $^{3,4} \cdot$ Erica Rowan $^{5}$ \\ Published online: 21 November 2018 \\ (c) The Author(s) 2018
}

\begin{abstract}
The excavation of an ancient sewer in the town of Herculaneum, Italy, provided the opportunity to study Roman diet in the Bay of Naples, including the marine component. The sewer served an apartment block which was buried by the eruption of Vesuvius in AD 79 and retained human and kitchen waste of the non-élite individuals living above. The remains showed a high degree of dietary diversity with around 70 fish, 48 marine mollusc and three marine arthropod taxa being identified. The fish were mostly small individuals which were probably netted in fairly shallow, coastal waters. The marine invertebrates included species of sandy shores, rocks and the sea bed but the majority could have been collected very close to the water's edge. Both the fish and the shellfish would have been available locally in large quantities and probably represented cheap and nutritious dietary fare. Some of the consumed fish was probably salted (salsamenta) or fermented (as fish sauces such as garum), but it is thought that most of the fish and shellfish originated in the Bay of Naples and would have been purchased fresh. The difficulty of identifying preserved fish within the mixed sewer assemblage is discussed.
\end{abstract}

Keywords Herculaneum $\cdot$ Roman $\cdot$ Fish $\cdot$ Molluscs $\cdot$ Diet $\cdot$ Sewer

\section{Introduction}

Herculaneum was a small Roman town situated on the Bay of Naples, Italy. It was buried by the great eruption of Vesuvius in AD 79 which also covered Pompeii. In 2007 the Herculaneum Conservation Project excavated the NE-SW branch of the Cardo V Sewer which runs beneath Insula Orientalis II.6-14. This sewer was part of the Palaestra development,

Rebecca Nicholson

rebecca.nicholson@oxfordarch.co.uk

Oxford Archaeology South, Janus House, Osney Mead, Oxford OX2 0ES, UK

2 c/o Mark Robinson at the Natural History Museum, Oxford University Museum of Natural History, Parks Road, Oxford OX1 3PW, UK

3 Oxford University Museum of Natural History, Parks Road, Oxford OX1 3PW, UK

4 School of Archaeology, University of Oxford, South Parks Road, Oxford OX1 3TG, UK

5 Department of Classics, Royal Holloway, University of London, Egham, Surrey TW20 0EX, UK 
which comprised a ground floor of shop units, including a taberna vinaria (wine shop) and a bakery, with two floors of rental apartments above for domestic accommodation (Camardo 2008; Wallace-Hadrill 2012: 271-85). It provided a unique opportunity to examine seafood procurement and consumption for an assemblage of precise age and provenance. The sewer system contained thick deposits of unexcavated sewage and general food-preparation waste which would have been thrown down the latrine shafts from the ground floor shops and apartments above the sewer in about the 10 years prior to the eruption. In contrast to the pit latrines at Pompeii, the Cardo V Sewer collected waste horizontally rather than vertically, and this, together with the lack of an outflow for solids, resulted in the accumulation of over $1 \mathrm{~m}$ of material over a length of $53 \mathrm{~m}$ which was sealed by ash from the eruption. In effect this sewer system acted as a large cesspit, the remains of fish and shellfish found within which reflect foods prepared and eaten by the inhabitants of this district.

Since the faunal remains were recovered from areas directly beneath apartments used for domestic and commercial activities it was hoped that spatial analysis would help further to refine the investigation of the dietary habits and social status/wealth of the inhabitants living above or close to the sampled quadrants. In addition, the remains testify to the fishing and shellfish collection strategies practised by the townsfolk and, potentially, to wider procurement through trade.

\section{Method and Materials}

The sewer was excavated in 53 one metre quadrants (designated Q1-53). Each quadrant was divided into layers (US) based on the stratigraphy of the whole sewer, each layer receiving identical identification numbers (Fig. 1). Samples were selected and processed by a team from the University of Oxford led by M. Robinson: 10 litres of sediment from each layer, in alternating quadrants, was wet-sieved, starting with Q1-2. In total 11,625 litres of material was removed in 799 sample bags, of which 1140 litres was processed on site. In each case, after flotation the heavy residues were dried and sieved into size fractions, and the $>2 \mathrm{~mm}$ residues from selected samples entirely sorted. Additionally, for many samples, $25 \%$ of the 1-2 mm residues was also sorted as a check on the recovery of tiny remains. Full details of the excavation, sampling and sample processing methodologies, as well as archaeobotanical investigations and very preliminary findings from the ichthyofaunal study, have been presented elsewhere (Rowan 2014a, b, 2017). This paper presents a summary of the results of more detailed work, by Nicholson and J. Robinson respectively, on the fish remains and shellfish recovered. In time a full report on the assemblages will be produced as part of the archaeological study. ${ }^{1}$

Owing to the richness of the samples and the time available for study, it was not possible to identify the fish remains from every processed sample and instead bones and scales from 34 samples were recorded, comprising all samples from six quadrants evenly spaced along the length of the sewer as well as a selection of samples from six intervening quadrants chosen for more detailed work if less common taxa were seen after a quick scan. Identifications were undertaken with the aid of comparative fish reference collections (of Nicholson and Hamilton-Dyer) as well as illustrated manuals (particularly Roselló-Izquierdo 1986) and

\footnotetext{
1 Further details about the distribution of fish within the sewer can be found in the site archive and report prepared for eventual inclusion in the publication of the Cardo $\mathrm{V}$ excavation.
} 


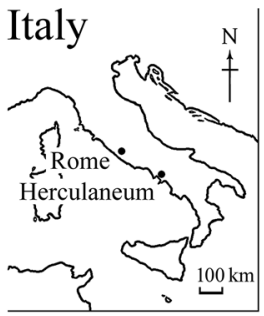

\section{Cardo V Sewer}

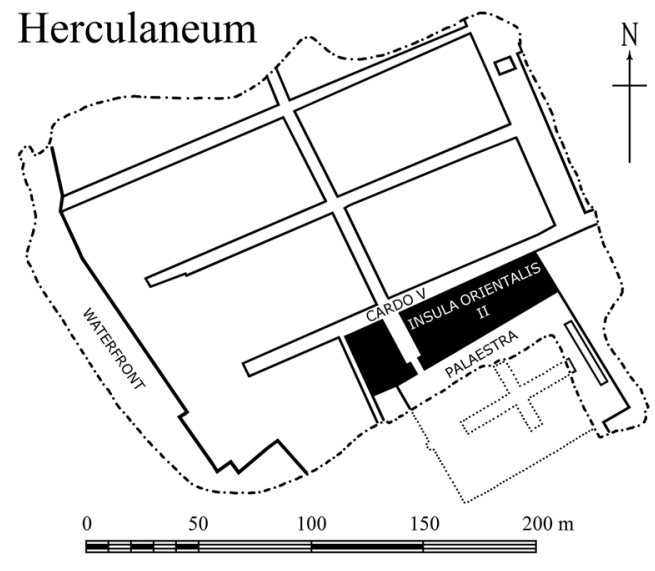

and Insula Orientalis II

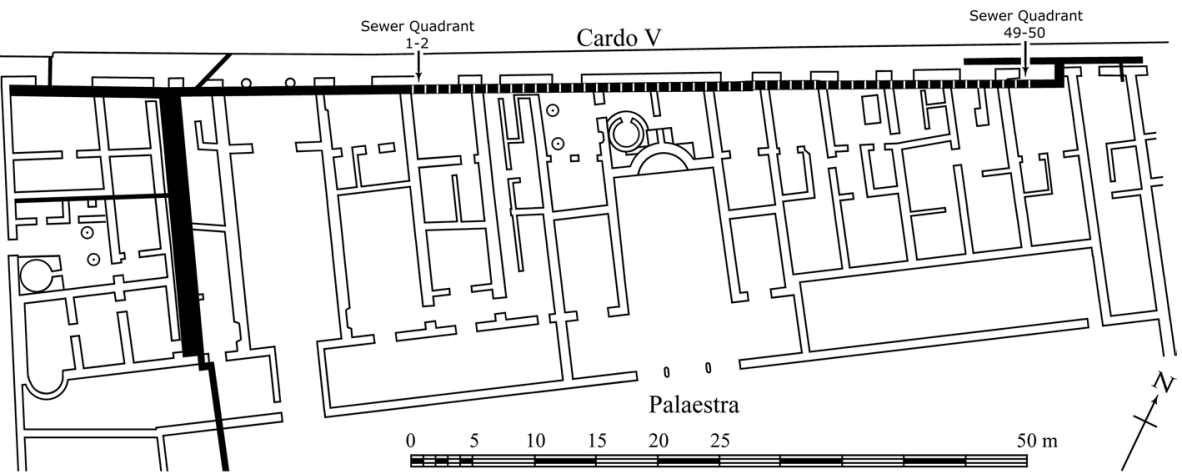

Fig. 1 Location of Cardo V and the sewer at Herculaneum

nomenclature follows Fishbase (Froese and Pauly 2000, 2018). ${ }^{2}$ Quantifications are by number of identified specimens only, since cranial elements were absent or rare for some taxa rendering the calculation of minimum numbers of individuals (MNI) fairly pointless. It is important to note here that the great majority of bones were extremely small and often fragmented, necessitating the use of a low-power stereo microscope. This, as well as the diversity of fish remains in the samples, has led to a significant proportion of the bones being identified only to family level, remaining tentatively identified or unidentified. Also because of the very small size of the great majority of bones, as well as crushing/fragmentation, bone measurements were not taken. Where fish sizes are indicated these are estimates of the total length of the fish based on visual comparison with modern reference material, coupled with a subjective estimate of the size of the fish in relation to the size-ranges exhibited by the species (i.e. tiny, small, medium, large). It should be noted that in future otolith measurements could be utilised for size reconstruction particularly for the Sparidae. Investigation of the otoliths was undertaken separately, by Rowan (2014a) and was limited to the use of the AFORO online image-analysis database (Lombarte et al. 2006).

In contrast to the methodology used for the fish assemblage, shells from all the processed samples were identified. This was undertaken using a reference collection (of

${ }^{2}$ https://www.fishbase.de. Accessed June 2018. 
J. Robinson) gathered in the Bay of Naples, together with a published guide (Parenzan 1970-76). Quantification is by minimum numbers of individuals for gastropods and bivalves (the greater of the numbers of left and right valves). Nomenclature follows Sabelli et al. (1990-92).

\section{Description of Assemblages}

\section{Fish}

The studied fish assemblage comprised an estimated 2500 identified bones from about 70 species of fish (Table 1). Apart from cranial and post-cranial bones, otoliths (distinctive calcium carbonate structures in the inner ear) were extremely common in the samples and many were identified by Rowan (2014a). Curiously, few non-bony scales of fish were found, although they are sometimes abundant in samples from Pompeii.

The assemblage is typified by high species diversity and is highly dominated by the remains of small (under ca. $25 \mathrm{~cm}$ ) and tiny (under ca. $15 \mathrm{~cm}$ ) fish, particularly juveniles of Sparidae [sea breams and picarel, formerly Centracanthidae (see Santini et al. 2014)] as well as Trachurus sp. (horse mackerels), Sardina pilchardus (sardine), Conger conger (conger eel), Muraenidae (moray eels), Labridae (wrasses), Triglidae (gurnards) and small flatfishes. Although a few clupeid vertebrae were more similar to Clupea harengus (Atlantic herring) than to Sardina pilchardus (sardine), the identification of these as an imported fish (herring) is unconfirmed since clupeid vertebrae can be difficult to speciate. While virtually all the identified fish bones came from marine taxa, a very few bones from small cyprinids (Cyprinidae) including Rutilus rutilus (roach) and probably Abramis brama (bream) demonstrate limited consumption of freshwater fish, as may the few bones from the catadromous Anguilla anguilla (eel) although some of these fish spend their entire life in coastal or estuarine waters. A fragment of Salmonidae (salmon or trout) vertebra is most likely to have come from an imported, preserved fish.

Generally, the fish remains are more abundant and diverse in samples taken from the southern end of the sewer, but this is likely to reflect the drift of sewer contents to this end of the sealed system, with smaller and lighter elements moving more easily. The very few bones from larger fish (here defined as fish with total lengths of at least est. $40 \mathrm{~cm}$ ) mostly came from samples from the middle to northern end of the sewer. Zeus faber (john dory), large gurnard, Lophius sp. (anglerfish) and small tuna (i.e. Auxis sp.), for example, were identified in quadrants $33-34,45-46$ or $49-50 .^{3}$ There are no examples of particularly large fish.

\section{Molluscs}

Shellfish were identified in all 76 samples that were processed. Table 2 provides the minimum number of individuals for gastropods and bivalves. In addition, fragments of the internal shell of the cephalopod Sepia sp. (cuttlefish) were found in several samples. The only remains of a non-molluscan marine invertebrate found in abundance were test fragments and spines of the echinoderm Paracentrotus lividus (Lam.) (rock or purple

\footnotetext{
${ }^{3}$ See footnote 4 .
} 
Table 1 Fish NISP (number of identified specimens)

\begin{tabular}{lll}
\hline Taxon & English name & $\begin{array}{l}\text { Number of iden- } \\
\text { tified specimens }\end{array}$ \\
\hline
\end{tabular}

\section{PISCES}

Pleurotremata

Shark unspecified 1

Squalidae

Dogfishes 2

Elasmobranchii

Shark or Ray

Rajidae

Rays unspecified

cf. Raja undulata (Lacépède)

?Undulate ray

Raja clavata $\mathrm{L}$.

Thornback ray

Anguillidae

Eel unspecified

Anguilla anguilla (L.)

European eel

Conger conger (L.)

Conger eel

Muraena helena $\mathrm{L}$.

Moray eel

Clupeidae

Sardina pilchardus (Walbaum)

Herrings unspec.

Sardine

cf. Clupea harengus L.

?Atlantic herring

Engraulis encrasicolus (L.)

Salmonidae

*Cyprinidae, cf. Abramis brama (L.)

Anchovy

Salmonid unspec.

?Bream

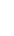

*Rutilus rutilus (L.)

Roach

Garfish

Garfish/Saury

Belonidae

Atherina presbyter Cuvier

Lophius sp.

Sandsmelt

Anglerfish 2

Gadidae

Trisopterus sp.

Merluccius merluccius (L.)

Phycis blennoides (Brünnich)

Zeus faber (L.)

Sygnathidae

Scorpiaenidae

Cod family unspec. 9

Poor cod/pout 16

Hake 13

Forkbeard 2

John dory 1

Pipefishes 2

Scorpion fish unspec. $\quad 17$

Scorpaena scrofa L.

Triglidae/Peristediidae

Peristedion cataphractum (L.)

Red scorpion fish 1

Gurnards unspec. $\quad 39$

Chelidonichthys cuculus (L.)

Armoured sea robin 8

Red gurnard 1

Long finned gurnard 1

cf. Chelidonichthys obscurus (L.)

Grey gurnard 2

$\begin{array}{lll}\text { Lepidotrigla cavillone (Lacépède) } & \text { Large scaled gurnard } & 11\end{array}$

Cottidae?

Cottids 6

Dicentrarchus labrax (L.) $\quad$ European sea bass 5

Epinephelus sp. $\quad$ Grouper 1

$\begin{array}{lll}\text { cf. Epinephelus marginatus (Lowe) } & \text { ?Dusky grouper/merou }\end{array}$

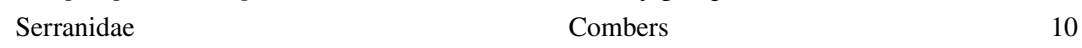

Serranus sp.

$\begin{array}{lll}\text { Serranus atricauda Günther } & \text { Blacktail comber } & 2\end{array}$

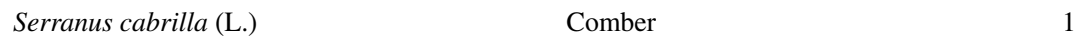


Table 1 (continued)

Taxo

English name

Number of iden-

tified specimens

Serranus scriba (L.)

Painted comber

1

Blennidae

Blenny unspec.

Parablennius cf. sanguinolentus (Pallas)

?Rusty blenny

Parablennius gattorugine (Brünnich)

Tompot blenny

Carangidae

Lichia amia (L.)

Jacks

Leerfish

cf. Lichia amia

?Leerfish

1

Trachurus trachurus (L.)

Atlantic horse mackerel 93

Trachurus sp.

Horse mackerels $\quad 59$

Gobidae

Goby unspec.

Gobius niger (L.)

Black goby

Labridae

Coris julis (L.)

Symphodus mediterraneus (L.)

Wrasses unspec. $\quad 41$

Rainbow wrasse 14

Axillary wrasse 4

Ctenolabrus rupestris (L.)

Goldsinny wrasse

Cuckoo wrasse

Symphodus melops (L.)

Mugilidae

Corkwing wrasse

Grey mullets unspec.

cf. Chelon labrosus (Risso)

?Thick lipped grey mullet

Mullus sp.

Mullus surmuletus L.

Red mullet/goatfish $\quad 13$

Red mullet 1

Chromis chromis (L.)

Damselfish

?Damselfish

Scaridae

Sciaenidae

Umbrina cirrosa (L.)

Parrotfishes unspec. $\quad 2$

Drums/Croakers 1

Shi drum 1

Sparidae

Seabreams and picarels unspec. 200

Boops boops (L.)

Bogue

?Annular seabream 2

Diplodus sargus (L.)

White seabream

Diplodus sp.

Oblada melanura (L.)

Pagellus bogaraveo (Brünnich)

Saddled seabream 9

Pagellus erythrinus (L.)

Red seabream

Pandora

Sarpa salpa (L).

Saupe

Sparus aurata L.

Pagrus pagrus (L.)

Gilthead seabream 1

Red porgy 2

Pagellus/Pagrus/Sparus sp.

Sea bream 19

Spondyliosoma cantharus (L.)

Black seabream 16

Spicara maena (L.)

Blotched picarel 1

Spicara sp.

Picarel

Sphyraena spyraena

Barracuda

Trachinidae

Weevers unspec.

Trachinus draco L.

Greater weever 
Table 1 (continued)

\begin{tabular}{|c|c|c|}
\hline Taxon & English name & $\begin{array}{l}\text { Number of iden- } \\
\text { tified specimens }\end{array}$ \\
\hline Uranoscopus scaber L. & Stargazer & 15 \\
\hline Scombridae & Mackerels/Small tunas unspec. & 130 \\
\hline Auxis thazard (Lacépède)/rochei (Risso) & Frigate/bullet tuna & 5 \\
\hline cf. Euthynnus alletteratus (Rafinesque) & ?Little tunny & 1 \\
\hline Scomber colias Gmelin & Spanish/chub mackerel & 7 \\
\hline Scomber sp. & Mackerel unspec. & 11 \\
\hline Pleuronectiformes & Flatfish unspec. & 53 \\
\hline Citharus linguatula (L.) & 4-spot flounder & 16 \\
\hline Bothidae/Scopthalmidae & Left-eyed flatfish unspec. & 8 \\
\hline Bothidae & Left-eyed flatfish & 8 \\
\hline Arnoglossus sp. & Scaldfish unspec. & 10 \\
\hline Arnoglossus laterna (Walbaum) & Mediterranean scaldfish & 4 \\
\hline Scophthalmidae & Turbots unspec. & 16 \\
\hline cf. Scophthalmus maximus (L.) & ?Turbot & 1 \\
\hline Lepidorhombus whiffagonis (Walbaum) & Megrim & 2 \\
\hline Lepidorhombus sp. & & 4 \\
\hline Pleuronectidae & Right eyed flatfish unspec. & 12 \\
\hline Platychthys flesus (L.) & Flounder & 1 \\
\hline Soleidae & Soles unspec. & 8 \\
\hline Solea cf. solea (L.) & Sole & 2 \\
\hline Balistidae & Triggerfish & 8 \\
\hline Unidentified & & 3025 \\
\hline Total & & 5434 \\
\hline
\end{tabular}

*Freshwater fish

sea urchin), which were present in most samples. There were also several fragments of Sessilia indet. (barnacle) and a chellicera of Eriphia verrucosa (Forsk.) (warty crab).

Most of the mollusc shells represented kitchen or table waste but there was a significant presence of taxa with an adult size below $12 \mathrm{~mm}$ which would now be regarded as too small to collect for food. The assemblage was very species-rich but shells of just six taxa made up 83\% of the individuals (Fig. 2): Donacilla cornea (corneous wedge shell), Patella sp. (limpet), Mytilaster cf. minimus (dwarf mussel), Pecten jacobeus (pilgrim scallop), Bolinus brandaris (purple dye murex) and Aequipecten opercularis (queen scallop). The Italian word 'tellina' describes seafood comprising wedge shells (Donax) and similar species. The tellina Donacilla cornea was the most frequent and numerous yet also conspicuously small as a common foodstuff, typically 10-22 mm long. The tiny Mytilaster, too small for food, was rare except in one quadrant with 52 shells. Apart from Tonna galea (dolium shell), which has a fragile shell, remains from large shells were absent and there were no finds of the very large species such as Charonia nodifera (Triton's trumpet) which feature prominently amongst the early records from Pompeii. A few shells were plainly harvested after the death of the mollusc, notably 
Table 2 Marine gastropod and bivalve MNI (minimum number of individuals)

\begin{tabular}{lll}
\hline Taxon & English name & $\begin{array}{l}\text { Minimum num- } \\
\text { ber of individuals }\end{array}$ \\
\hline
\end{tabular}

\section{GASTROPODA}

Patella sp.

Limpet

254

Diodora italica (Def.)

Calliostoma granulata (von B.)

Gibbula albida (Gmel.)

G. philberti (Récl.)

Gibbula sp.

cf. Cerithium sp.

Bittium sp.

Cerithiidae indet.

Turritella communis Riss.

Naticidae indet.

Tonna galea (L.)

cf. Narrimania concinna (Syk.)

Bolinus brandaris (L.)

cf. Bolinus brandaris (L.)

Hexaplex trunculus (L.)

cf. Hexaplex trunculus (L.)

Ocenebra erinaceus (L.)

Ocinebrina aciculata (Lam.)

O. edwardsii (Pay.)

Fusinus pulchellus (Phil.)

Nassarius cf. corniculus (Olivi)

N. mutabilis (L.)

$N$. cf. costulatus cuvierii (Pay.)

Stramonita haemastoma (L.)

Muricidae indet.

Columbella rustica (L.)

Conus mediterraneus Hwass in Brug.

Odostomia eulimoides Han.

BIVALVIA

Arca noae L.

Glycymeris insubrica (Broc.)

Glycymeris sp.

Mytilus galloprovincialis Lam.

Mytilaster cf. minimus (Poli)

Gregariella cf. petagnae (Sca.)

Lithophaga lithophaga (L.)

Modiolula phaseolina (Phi.)

Mytilidae indet.

Pecten jacobeus (L.)

Aequipecten opercularis (L.)

Spondylus gaederopus L.

Ostrea edulis L.
Italian keyhole limpet

Granular topshell

Whitish gibbula

Cerith

Needle whelk

Needle shell

Common tower shell

Necklace shell

Dolium shell

Purple dye murex

Purple dye murex

Banded dye murex

Banded dye murex

Sting winkle

Sharp dwarf winkle

Edwards' dwarf winkle

Spindle shell

Horn nassa

Changeable nassa

One-banded nassa

Red mouthed rock shell

Murex

Rustic dove shell

Cone

Noah's ark shell

Dog cockle

Dog cockle

Mediterranean mussel

Dwarf mussel

Half hairy mussel

Date mussel

Bean horse-mussel

Mussel

Pilgrim scallop

Quin scallop

Thorny oyster

Common oyster

3

71

2 
Table 2 (continued)

\begin{tabular}{lll}
\hline Taxon & English name & $\begin{array}{l}\text { Minimum num- } \\
\text { ber of individuals }\end{array}$ \\
\hline
\end{tabular}

cf. Ostrea edulis L.

$\begin{array}{lr}\text { Common oyster } & 4 \\ \text { Oyster } & 5 \\ \text { Sand cockle } & 1 \\ \text { Warty cockle } & 2 \\ \text { Warty cockle } & 9 \\ \text { Common cockle } & 3 \\ \text { Common cockle } & 2 \\ \text { Cockle } & 7 \\ \text { Corneous wedge shell } & 2 \\ \text { Razor shell } & 768 \\ \text { Thin-walled tellin } & 2 \\ \text { Abrupt wedge shell } & 1 \\ \text { Striped Venus } & 29 \\ \text { Oval Venus } & 9 \\ \text { Carpet-shell } & 1 \\ \text { Golden carpet-shell } & 28 \\ & 1476\end{array}$

Ostreidae indet.

Lucinella divaricata (L.)

Acanthocardia spinosa (Sol.)
A. tuberculata (L.)
cf. A. tuberculata (L.)

Cerastoderma edule (L.) or glaucum (Poir.)

cf. Cerastoderma edule (L.) or glaucum (Poir.)

Acanthocardia or Cerastoderma sp.

Donacilla cornea (Poli)

Ensis minor (Che.)

cf. Tellina tenuis da C.

Donax trunculus L.

Chamelea gallina (L.)

Timoclea ovata (Pen.)

Tapes decussatus (L.)

Paphia aurea (Gmel.)

Total minimum number of individual gastropods $\&$ bivalves

1476

\section{CEPHALOPODA}

Sepia sp. cuttlefish
5

2

9

3

2

7

2

768

2

1

29

9

1

28

1

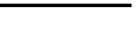


the Lithophaga lithophaga (date mussel), and so were fishing waste rather than food remains. Shells seem not to have moved along the sewer.

\section{Discussion}

\section{Seafood in the Roman World}

That fish were a regular feature of Roman dining is well known and there is no doubt that some fish were an expensive food or status symbol- many classical scholars allude to fish as being an élite or luxury foodstuff (e.g. Pliny $H N$ 9.27-32) ${ }^{4}$ and both fish-eating and fishrearing have been considered to be symbols of wealth. Fresh and salt water Piscinae were built at some villas around Herculaneum and Pompeii as a demonstrable status symbol (Reese 2002a) and fish feature on mosaics and wall paintings around the Roman Empire (Marzano 2013: 21-27). However, while there are hints that some fish are less favourede.g. mud and coastal mullet and perhaps some sea bream (Pliny HN 9.30), ${ }^{5}$ Pliny the elder and other scholars do not focus their attention on foods for the general masses and consequently there has been little discussion about the role of fish in the diet of the general population in Roman Italy. Archaeological evidence is fairly scant too: Reese (2002a) commented that for the Pompeii area mosaics and wall paintings provide more information regarding fish than do preserved bones and while early excavations at Pompeii refer to the finding of fish bones these were not saved or identified. More recently, where excavations have taken place fish remains seem infrequent or often absent. Even at Pompeii, apart from the well-known deposits of bones associated with garum production (Carannante 2008-9), assemblages tend to be quite small (Locker 1999) ${ }^{6}$ and this is true for deposits that were wet sieved as well as those that were not and probably reflects the kinds of deposits. Few latrines have been excavated at Pompeii; they tend to be dangerous deep shafts where it is difficult to reach the sewage deposits. No sewer deposits comparable to those at Herculaneum have been discovered.

Marine molluscs and other marine invertebrates were a customary, albeit relatively minor, part of the diet in the Roman Mediterranean world. Classical authors do not give them the same attention as fish but they are often depicted in the same mosaics and wall paintings at Pompeii that show fish. The shells of marine molluscs are usually robust and survive well in the calcareous soils of Pompeii and Herculaneum. Larger shells are conspicuous items which tend to be collected during excavations and shells were sometimes used to decorate fountains or mounted as garden ornaments. By the late 19th century, sufficient shells had been found at Pompeii for their occurrence to be usefully reviewed (Tiberi 1879). As excavation continued, so shells continued to be saved, though rarely with detailed context information. Reese (2002b) reports on specimens of 51 taxa from Pompeii and Herculaneum. Over the past 25 years, there have been many more excavations below the AD 79 ground level at Pompeii and large-scale sieving which has recovered even the smallest of shells but few results have been published.

\footnotetext{
4 In Rackham 1983: 203-205.

5 In Rackham 1983: 207.

6 Also unpublished assemblages from the house of Potsumi (report by RA Nicholson), from Houses 11 and 12 (report by A Locker).
} 


\section{Habitats}

\section{Fish}

Compared to larger oceans the Mediterranean is relatively poor in marine life, nevertheless about 700 species of fish are listed as inhabiting the Mediterranean Sea today, 447 in the southern Tyrrhenian Sea, including all of the marine taxa identified in the Herculaneum assemblage, ${ }^{7}$ with the exception of Cottidae (cottids) (Psomadakis et al. 2012). ${ }^{8}$ Many of the identified taxa are also included in recent lists of fish found in and around the seagrass (Posidonia) beds located in the Bay of Naples and close to the island of Ischia. In a survey of these seagrass beds by Zupo and Stübing (2010), 28 species of fish were identified all of which, with the exception of eels and pipefish, were under $15 \mathrm{~cm}$ long, and many of which were under $10 \mathrm{~cm}$ long. These fish included several Labridae (wrasses), Chromis chromis (damselfish), Scorpaenidae (scorpion fishes), Serranidae (combers), Gobiidae (gobies), Syngnathus acus (pipefish), Mullus surmeletus (red mullet), Conger conger (conger eel), Diplodus annularis (annular sea bream), Spicara maena (picarel), Arnoglossus kessleri (scaldfish) and Bothus podas (wide-eyed flounder). Other fish identified in the Herculaneum assemblage that may have frequented these habitats include small groupers (Epinephelus sp.) and possibly Scaridae (parrotfish) and Balistidae (triggerfish) although parrotfish are rare in the north-western Mediterranean today ${ }^{9}$ (Kruschel et al. 2012) and triggerfish do not typically feature in archaeological assemblages from this region (Mylona pers. comm.) although Balistes capriscus (grey triggerfish) is present in the Tyrrhenian Sea (Psomadakis et al. 2012). Although the volcanic eruptions have altered the coastline around Herculaneum it is very likely that these coastal seagrass beds existed or were even more extensive at the time of the AD 79 eruption and that many of the fish identified in the sewer samples came from this environment or from rocky inshore waters. Juvenile fish, including Dicentrarchus labrax (sea bass), combers, groupers and Merluccius merluccius (hake), as well as dogfish, flatfish and rays would also frequent shallow coastal waters, around rocks or man-made structures such as the harbour wall.

The other main category of fish identified in the Herculaneum material are pelagic and shoaling species including sardine, Engraulis encrasicolus (anchovy), horse mackerel, Belone belone (garfish) and Boops boops (bogue) which would have been netted seasonally, in quantity, probably during the summer months when they are found in coastal waters. Juvenile horse mackerel may shoal with pilchards (sardines) and bogue to form a mixed catch (Louisy 2015: 65). These fish are those most likely to be constituents in fish sauces (see below) but they may also have been marketed as fresh fish.

\footnotetext{
7 With the exception of Cottidae (cottids): Taurulus bubalis (sea scoropion) is found in the Ligurian Sea but not currently in the Tyrrhenian Sea (Psomadakis et al. 2012).

8 The possible significance of cottid bones was not recognised when the assemblage was identified and since none of the more diagnostic jaw elements were present the species identifications are considered tentative.

9 Regarding parrotfish, Pliny the Elder recorded that Tiberius had wrasse (thought to be probably parrotfish, Sparisoma cretense) transported alive from the Carpathian Sea, an area of water between Crete and Rhodes, to restock the waters between the mouth of the Tiber and Ostia (Pliny 9.29 cited in Rackham 1983: 205; Boetto 2010: 247).
} 
As small individuals the few freshwater fish were probably caught locally, perhaps from a small-scale riverine fishery upstream in the River Sarno. ${ }^{10}$ Similarly, a single Tinca tinca (tench) bone was recovered from an unstratified context at the House of Amarantus at Pompeii. ${ }^{11}$ Several species identified at Herculaneum including flounders, grey mullet and sea bass, tolerate brackish water and may have frequented the Sarno Estuary.

\section{Molluscs}

The molluscs and other invertebrates were all Mediterranean species which occur in habitats to be found in the Bay of Naples. The majority are inhabitants of shallow water, in some instances almost to the limit of the slight tidal range. They reflect the range of habitats along the Roman coastline. The species of rocky habitats included Patella sp. (limpet) which adheres to rocks, Mytilaster cf. minimus (dwarf mussel) which clings to rocks with byssus threads, Lithophaga lithophaga (date mussel), which bores into calcareous rocks and the sea urchin Paracentrotus lividus, which lodges in holes in soft rocks. Sandy shores were represented by Donacilla cornea (corneous wedge shell) which is a shallow burrower where the waves break, Chamelea gallina (striped Venus) which favours slightly deeper water and Ensis minor (razor shell) which burrows deeply in sand. Other species occur in water $1 \mathrm{~m}$ or more deep on firm substrates, be they rocks or muddy sand with some shingle, over which they glide, such as the murexes (purple-dye shellfish) Bolinus brandaris and Hexaplex trunculus, or to which they attach themselves such as Arca noae (Noah's ark shell). The scallops Pecten jacobeus and Aequipecten opercularis rest on areas of flat seabed but readily swim, Sepia sp. (cuttlefish) is adept at swimming. Unlike for the fish, Posidonia beds were not a major habitat for the molluscs, probably because there are few economic species which live there although some of the small gastropods such Columbella rustica (rustic dove shell) crawl on the leaves of Posidonia and A. noae attaches itself to the rhizomes. P. lividus also occurs in Posidonia beds. There was one freshwater mollusc, cf. Anodonta cygnea (swan mussel).

Some indication of the size of the catchment for the shellfish at Herculaneum is given by a comparison with the composition of a large assemblage of molluscs identified from the Porta Stabia excavations at Pompeii, $13 \mathrm{~km}$ SE along the coast (J. Robinson, unpublished). The assemblages are broadly similar with limpets and tellina particularly abundant in both. However, the tellina Donacilla cornea was absent from Pompeii, its place being taken by Donax trunculus. D. trunculus was found in the Herculaneum sewer but only comprised $3.6 \%$ of the combined total of individuals of the two species. Both have apparently similar ecological niches, occurring in shallow water up to the water's edge where the bed is sandy, and they can be extremely abundant. However, their abundance on sandy beaches and therefore their competitive advantage against each other is determined by subtle habitat differences including the grain size of the sand and the degree of wave action (de la Huz et al. 2002; la Valle et al. 2011; Mavidis et al. 2006). Presumably, the beaches around Herculaneum favoured $D$. cornea whereas the coast at Pompeii favoured $D$. trunculus, possibly due to the supply of fine sand from the mouth of the River Sarno which gave rise to extensive dunes between Pompeii and Stabia.

\footnotetext{
10 Although it is worth noting that the native distribution of freshwater fish in southern Italy is not well understood, particularly due to the widespread introduction of species (Gallo et al. 2012).

11 Undated report by Alison Locker, cited in Reese 2002b. This record does not appear in Locker 1999, which details the rest of the fish from the House of Amarantus (I.ix.11-12).
} 


\section{Methods of Capture}

\section{Fish}

In the coastal waters of the Mediterranean even small-scale fishing could produce quite large catches and Roman fishers utilised a variety of equipment adapted to different aquatic environments and types of fish, pelagic, benthic or migratory (Bekker-Nielsen 2010: 188). A wide range of net types were available suited to the size and behaviour of the targeted fish, water depth and current, and some of these were described in Oppian's Haleutica (Bekker-Nielsen 2010: 201). Most of the fish from the sewer samples were probably caught in nets similar to the carbonised example previously found from Herculaneum (BekkerNielsen 2010: 201) with fishermen operating from small boats like the gozzos used today and a vessel recovered from the ancient shoreline at Herculaneum. The recovery of the fishing boat Fiumicino 5 (late 2nd century AD) from the harbour at Ostia confirms literary evidence for the use of fish-well vessels to land living fish for the markets. It is likely that the rare examples of larger and solitary fish, such as john dory, may have been caught on a baited hook. Apart from the boat and carbonised net, finds recovered during excavations at Herculaneum include various sizes of hooks and lead fishing weights in addition to a wicker vessel containing the coiled remains of a long line, with many hooks attached (Bekker-Nielsen 2010: 201). Beach seines or dragnets hauled in by teams of fishers were probably used to capture a wide range of coastal species including inshore shoaling fish, such as Scomber scombrus (mackerel) and sardines, as well as bottom-dwelling fish including flatfish, Uranoscopus scaber (stargazer) and Trachinus draco (weever fish) which frequent sandy or muddy seabeds. The venomous nature of some of these fish was well known to the Romans: Pliny the Elder mentions the sting of weever fish (Pliny NH 9.72 in Rackham 1983: 268).

\section{Molluscs for Consumption}

Various means would have been needed to procure the shellfish that were being targeted for consumption. Others were probably bycatches of fishing which, depending on their utility, were either consumed or discarded. Patella sp. (limpets) can easily be prised off rocks in and just below the splash zone by clambering along the water's edge. Paracentrotus (sea urchin) can be grasped from below the water by using a long pole splayed at the end into four springy tines. Where there was a vertical cliff to the water, access could have been facilitated by boat.

Donacilla cornea (corneous wedge shell) can reach population densities of 2000 individuals per square metre under favourable conditions in the mid-tidal zone of sandy beaches (Mavidis et al. 2006: 192). It could readily be harvested by raking or digging over such localities at low tide. This would also retrieve other bivalves, such as Donax trunculus (abrupt wedge shell) and Tapes decussatus (carpet shell), which could be added to the catch. It is possible that there were also habitats on gently sloping sheltered beaches which could be raked over for Acanthocardia and Cerastoderma spp. (cockles).

The purple dye shellfish (known as murex) Bolinus brandaris and Hexaplex trunculus live in water too deep to be collected readily from the shore. Pliny describes their capture using baited wicker traps (Marzano 2013: 144-5) and Ruscillo (2005: 101-2) found a basket baited with rotting fish to be very effective in a harbour on Crete. They are also 
Fig. 3 Chewed and digested fish remains: a conger eel (Conger conger) vertebra showing characteristic distortion $\mathbf{b}$ hake (Merluccius merluccius) otolith, showing edge and surface erosion when compared with a modern specimen (right) [photograph by R. Nicholson] (a)

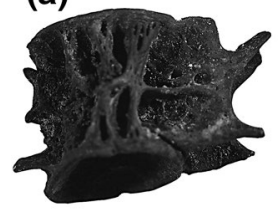

(b)

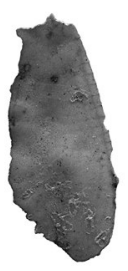

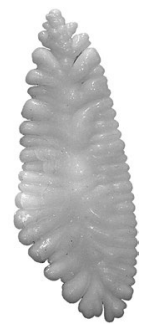

often dragged up by nets. The scallops Pecten jacobeus and Aequipecten opercularis were perhaps caught by using a simple dredge from a boat. This would also have served to harvest some of the other larger bivalves such as Ostrea edulis (oyster). The scallops along with Sepia sp. (cuttlefish) could also have been useful bycatches of netting for fish. Perhaps Tonna galea (dolium shell) was caught by diving.

\section{Small Molluscs as Contamination}

Some of the species identified either do not grow large enough to be considered for consumption or were only represented by small shells. Species such as Diodora italica (Italian keyhole limpet), Fusinus pulchellus, Modiolula phaseolina (bean horse-mussel) and the barnacles possibly entered the sewer because they were attached to larger shells being prepared for consumption in the apartments. Another possible source would arise if fish or shellfish were sometimes transported in baskets lined with Posidonia leaves to keep them cool and moist. Mytilus minimus (dwarf mussel) is a common member of the fouling community (Sarà et al. 2007: 68-69). Its occurrence in high numbers in two samples from the same quadrant suggests events of cleaning marine equipment at that location.

\section{Preserved Fish and Some Taphonomic Considerations}

A thick deposit of ash from the pyroclastic surges that destroyed Herculaneum filled the latrine shafts and sealed the organic remains within the sewer but was not sufficiently hot to cause charring. In this sealed environment bones discarded during meal preparation or as table waste are likely to have survived largely intact. However, although one of the primary constituents of material within a sewer will be human faeces, many fish bones that have been through the human digestive tract are likely to have been lost to the archaeological record, particularly if from fish with smaller and softer bones. Experiments have shown that bones which survive human digestion are biased towards denser elements (such as prootics and, potentially, otoliths) and are often significantly distorted or corroded (Jones 1986; Nicholson 1993). Although a proportion of bones within the sewer clearly arrived in sewage - a few fish were evidently eaten bones and all, as evidenced by numbers of chewed and corroded bones and otoliths with smoothed surfaces (Fig. 3)-many more must have come from plate scrapings and food preparation, since bone and otolith preservation was often excellent and most parts of the skeleton were present for many of the fish.

In this kind of depositional environment, it is worth considering how we might identify fish that had previously been salted or otherwise preserved. Large fish such as the bigger tunas were absent from the identified remains but may be under-represented in the sewer assemblage because the meat was sold to households as portions or steaks. 
Fig. 4 Mineralised fish scale from the Cardo V sewer (right) compared with a reference scale from frigate mackerel (Auxis thazard) [photograph by R. Nicholson]

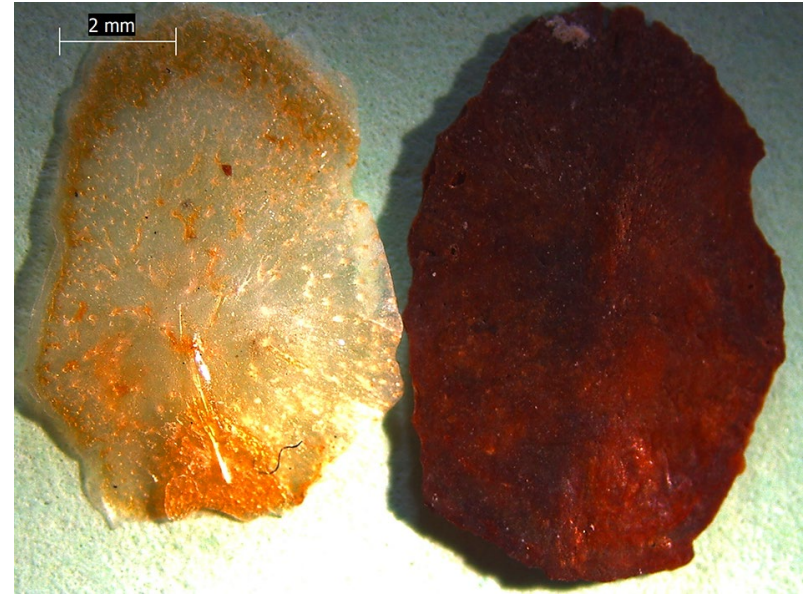

Pliny the Elder described the neck and belly of tuna as being eaten fresh, as delicacies while the body of the fish was preserved in salt (Pliny $H N$ 9.18). In this scenario it is possible that only the larger scales (found in a band around the body behind the head) would be present. Although fish scales were rarely preserved in the Herculaneum material, a few heavily mineralised Scombridae scales or fragments of Scombridae scales were found in most quadrants (Fig. 4) and may have come from salted fish portions (similar to the ones found in the 4th century Merchant's House in Corinth, Theodoropoulou 2014 and this volume). The representation of body parts suggests some eels may possibly have been purchased as beheaded, salted fish, since cranial elements were relatively scarce although they are typically fairly robust and readily identifiable (Table 3 ). This suggestion should be qualified, however, because eels have considerably more vertebrae than most other fish.

Any fish that were eaten whole (anchovies, small sardines etc.) or their bones consumed in products such as allec, are likely to be under-represented in the sewer samples, and the consumption of garum and liquamen will, of course, leave no trace as far as the fish bones are concerned (for further details of these products see Grainger, this volume). Even without consumption, it seems likely that the process of producing fish sauce would cause compositional changes to the hard tissues which would affect their chances of long-term survival. Both bones and scales (ctenoid and cycloid scales are a mineral composite made up of a layer of calcium-based salts and a fibrous layer largely made of collagen) are disrupted both by heating (e.g. during cooking or prolonged immersion in a warm liquid) and the action of enzymes during autolysis. The extent to which they survive these processes depends on the duration of exposure and this can be illustrated during the preparation of fish skeletons by immersion in water with the addition of proteases such as pepsin, or by boiling. In both cases scales are lost and bones become chalky if left too long. Whether bones used for fish sauce manufacture would be similarly degraded by the autolysis of fish tissues due to digestive proteases during the manufacturing of fish sauces is therefore an interesting avenue for research. Inspection by Grainger of the residues of herring and mackerel fermented during the preparation of fish sauce (Grainger 2013, 2014) indicated no macroscopically detectable effect on the bones, although the otoliths were not preserved. This is in sharp contrast to the condition of fish remains recovered archaeologically, from fish processing vats at the Casa do 


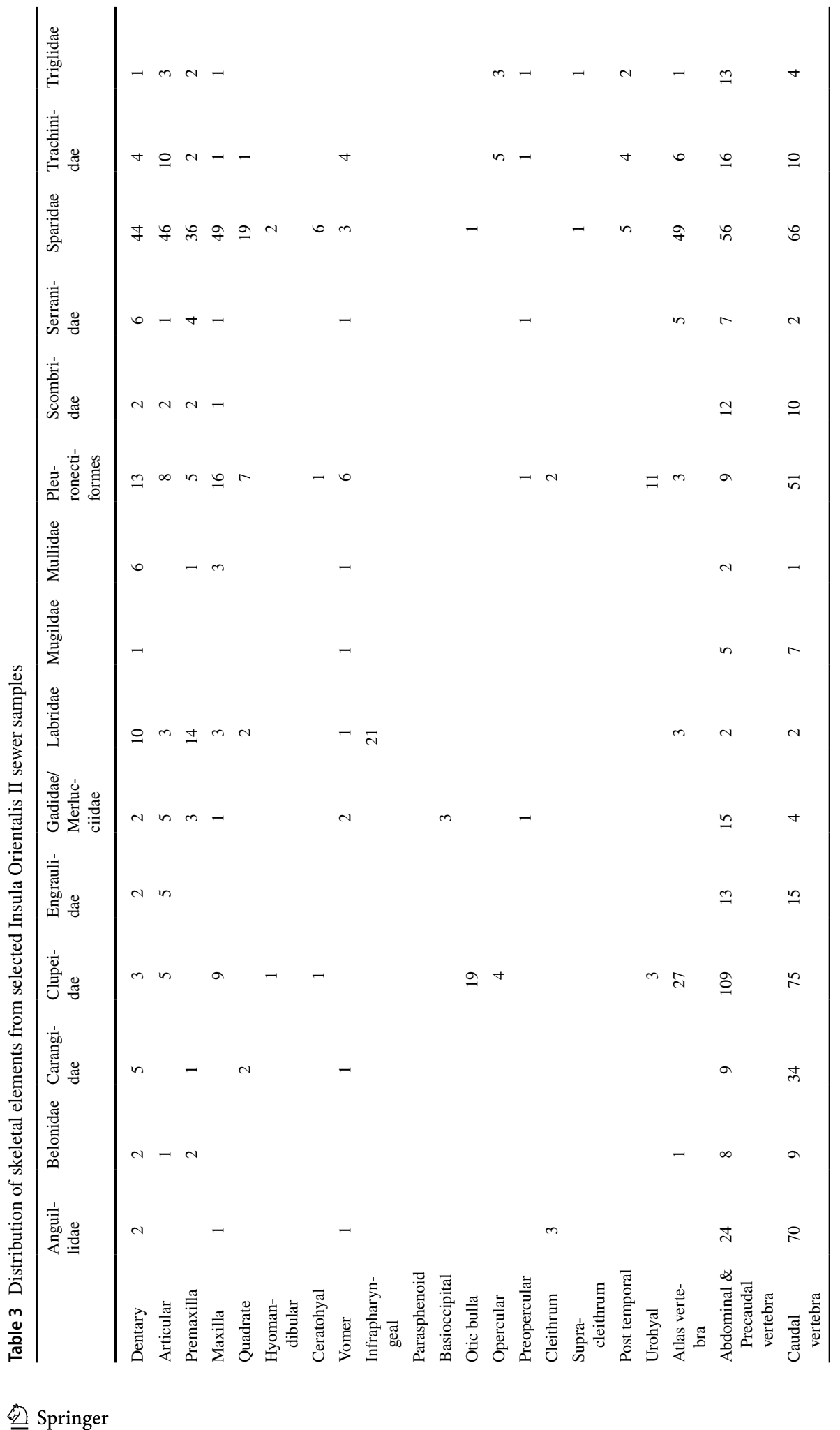




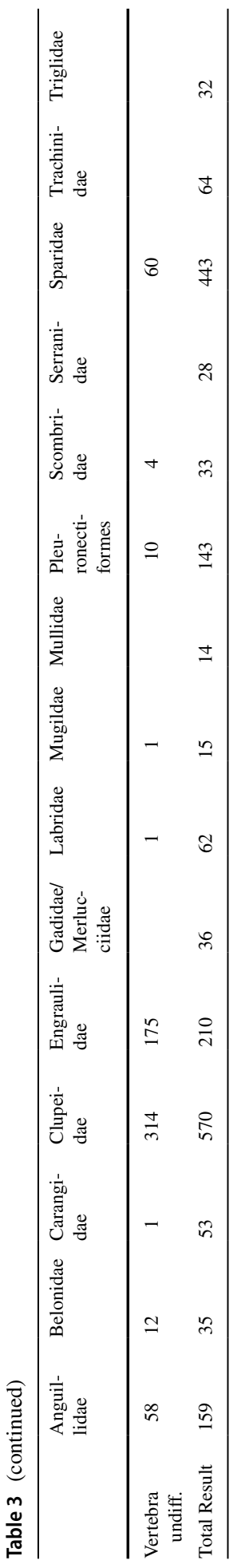


Governador, Portugal (Gabriel et al. 2009): these remains, almost entirely of sardines, comprise chalky textured vertebral centra and occasional otic bullae, the more fragile cranial bones and scales having entirely disappeared (R Nicholson: pers. obs.).

The difference in preservation between these two assemblages seems likely to relate both to the much greater age of the Portuguese specimens and, perhaps critically, conditions in the base of the processing vats which had a large surface area and may have been exposed to the elements after the vats were emptied. The corroded condition of the archaeological examples may also be related to the length of time taken to produce the sauces, and the likelihood that vats were not entirely emptied between batches (Grainger pers. com.). Given the rapid burial of the Herculaneum sewer fills and the subsequent protected burial environment, it is possible that any bones derived from the bony residues of fish sauces-i.e. allec-would not exhibit the extensive damage evident on the bones from the Casa do Governador. Nevertheless, some difference in condition between fermented fish and fresh fish could be anticipated, but in fact almost all of the bones in the sewer assemblage were in a similar condition and none appeared particularly corroded or chalky. Consequently, while many of the fish identified in the sewer samples are typical ingredients in fish sauces (sardines, anchovies and other small fatty fish such as mackerel, horse mackerel and garfish as well as picarel and small sea breams), it is uncertain whether any of the remains found in the sewer derived from these products.

The possible identification of herring in the assemblage is potentially significant since herrings are not found in the Mediterranean and if confirmed would indicate the importation of what might be a fairly low quality fish sauce from the northern Roman provinces (as described by Van Neer and Lentacker 1994). ${ }^{12}$ This aspect would benefit from further consideration if the fish assemblage is subjected to further study.

\section{Marine Food and the Consumer: Procurement, Preparation and Status}

It seems likely that the small mixed fish which comprise most of the Cardo V fish assemblage were purchased quite cheaply, probably as mixed fish in the markets or direct from fishing boats and cooked by frying (frittata) or by boiling as stews. The larger and more expensive fish were probably reserved for wealthier tables than those of the inhabitants of Insula Orientalis II. The preparation method used for small fried fish today is to remove the head, spine and guts in a single stroke- these remains would then be discarded and could well be those so common in the sewer. The greatest concentration of fish bones was recovered from quadrants from the SW end of the sewer, but this probably reflects the downward movement of the sewer contents rather than the fish-eating habits of the residents above. However, the identification of bones from john dory, Lichia amia (leerfish) and angler fish, as well as frigate mackerel and other small tunas, indicates that the residents of Apartments 11-14 may have been more affluent.

Given the wealth of documentary evidence and the huge processing vats that were used to supply processed fish products to the Roman world it is highly likely that fish sauces and pastes were commonly used in cooking by the residents of the apartments above the sewer. It is also obviously possible that some fish-such as anchovies, mackerel, scombrids, small sparids, clupeids and salmonid - may have been part of either locally produced or imported fermented and/or products, but as with the shellfish, the majority of fish are

${ }^{12}$ I am indebted to Arturo Morales for this point. 
much more likely to have originated in the Bay of Naples and been purchased fresh, probably at the local fish market or fishmonger. At nearby Pompeii, a taberna in the south-east corner of the macellum (VII.9.7) has been interpreted as a fishmonger's shop on the basis of its design and the presence of associated fish bones and scales (Marzano 2013: 289).

Although the physical remains of fish and shellfish have provided a valuable insight into the diet of ordinary townsfolk, the overall contribution of seafood to the diet is difficult to establish from this evidence from fish bones and sea shells alone. Here isotopic analysis of human skeletal remains has proved to be informative: recent isotopic investigation into the diet of Herculaneum residents killed by the Vesuvian eruption has been undertaken by Craig et al. (2013). By investigating the input of 'old' marine derived carbon into human skeletons found near the harbour they concluded that, with a $\delta 13 \mathrm{C}$ range of -20.2 to $-18.2 \%$, up to $30 \%$ of the carbon in collagen (mean 15\%) was derived from marine foods (Craig et al. 2013), with a much greater proportion coming from terrestrial foodstuffs of a similar carbon isotopic composition, probably cereals. Although the authors suggest these results indicate that marine foods were only a minor foodstuff, males appear to have consumed greater quantities than females (Martyn et al. 2018). When considered alongside the physical evidence from the Cardo V sewer, it is clear that seafood was eaten regularly, even if only as a relatively minor dietary component, which is what would be anticipated given the coastal location of the town.

All the shellfish could presumably have been collected by local fishermen ${ }^{13}$ but some of the most abundant species could also readily have been gathered by the occupants of the apartments themselves provided they had a right to exploit the shoreline. ${ }^{14}$ Limpets can be procured with only a stone or knife and a basket, many of the bivalves including Donacilla cornea (corneous wedge shell) can be harvested with a rake or shovel and a basket while it would not take long to cut sea urchin prongs.

The gonads of the sea urchin Paracentrotus lividus are commonly eaten raw and need to be very fresh. Otherwise, the shellfish were probably boiled alone or with grain. Most mollusc assemblages were mixed and it is likely that a range of species were cooked together. However, some quadrants contained groups of valves of Donacilla cornea, some of which could be paired. These possibly represented waste from plates of telline. The main shellfish groups eaten were tellini, limpets and (since many shells exceeded $50 \mathrm{~mm}$ ) purple dye-murexes, followed by scallops. Cockles (Acanthocardia spp. and Cerastoderma spp.) were few. Smaller mollusc taxa (limpets, tellini and cockles) reflected the size range sold or growing locally today. Of larger taxa, only immature shells or fragments entered the sewer.

Limpets are currently seen by Northern Europeans as a famine food. However, current inhabitants in the Pompeii area explained that they liked variety in texture in mixed seafood dishes, so included limpets because even when cooked they are tough and rubbery. The occurrence of their shells throughout most of the sewer therefore does not have status implications. Their absence from several quadrants including those of Houses 12-14 might reflect personal taste.

\footnotetext{
13 For further discussion of the professional organisation of fishermen and fishmongers and sale of fish see Marzano 2013: 38-50, 288-9; also Marzano this volume.

14 For a discussion of this topic see Ørsted (1998).
} 


\section{Secondary Uses of Molluscs}

Although primarily a food resource, seashells had connotations of beauty and fertility. A Pecten jacobeus (pilgrim scallop) valve was food-waste reused as a cosmetics container (Roberts 2013: 135). A Columbella rustica (rustic dove shell) pierced with 2 holes for suspension would, as a shell commonly found cast up on the strand, have been a cheap alternative to the cowries recorded as amulets from Pompeii (Tiberi 1879: 148-9). Similarly, the sea-worn Glycymeris (dog cockle) valve with a typical erosion hole through the umbone was not food-waste but would have been collected after the death of the mollusc.

\section{Conclusion}

The marine food remains from the Cardo V Sewer offer a glimpse of the fish and shellfish consumption of the townsfolk of Herculaneum. Although it is very likely that preserved fish, both salted and fermented (as fish sauces) were eaten, it has not been possible to demonstrate this unequivocally. It seems likely that almost all of the fish would have been caught in and around the Bay of Naples, using small boats similar to the gozzos in use today and using similar equipment, some of which has been preserved archaeologically (Bekker-Nielsen 2010; Marzano 2013: 28-32), or by seine netting from the shore as occurred into the 20th century. Shellfish were probably mostly gathered from the shore but boats were also used. It has been suggested that overfishing had caused fish stocks to be depleted even in Roman times. Although fish often appear as a luxury resource, gracing the tables of the élite (for examples see Marzano 2013: 287-9), the small and tiny fish typically found in the sewer samples must have been relatively cheap, since these kinds of fish could be caught in large quantities and the assemblages do not indicate significant selection in terms of size or species. Juvenal (Sat. 5. 92-96 in Green 1974) comments that the Mediterranean was overharvested so that fish in Italian waters were not reaching large sizes, and (as mentioned above) according to Pliny the Elder, the emperor Tiberius was engaged in fisheries management, having wrasse (parrotfish?) transported alive to restock the waters between the mouth of the Tiber and Ostia (Pliny $H N$ 9.29; Boetto 2010: 247). Although it would be tempting to use the Cardo V Sewer assemblage as evidence of over-fishing since the vast majority of bones were from small and in many cases juvenile fish perhaps indicating that larger fish were scarce, the fact that these fish appear to have been available in quantity suggests a sustainable resource with a similar range of species to that found in these waters today. As Koutrakis points out (this volume), despite systematic fishing and large-scale fish processing, the available evidence indicates that prior to the industrial era fish stocks were resilient and the level of fishing was sustainable.

Acknowledgements This research was carried out in the context of the Herculaneum Conservation Project (HCP: www.herculaneum.org), an initiative of the Packard Humanities Institute (and its Italian arm, the Istituto Packard per i Beni Culturali) in collaboration with the Soprintendenza Pompei. We are grateful for the access they provided to the material which was studied in the Oxford University Museum of Natural History and at Oxford Archaeology. We would like to thank Andrew Wallace-Hadrill and the HCP team, especially Sarah Court, for their continued assistance. Some of the fish remains were identified with the aid of Sheila Hamilton Dyer's reference collection and her generous help is gratefully acknowledged, as is the constructive advice provided by Dimitra Mylona and the referees of this paper. 
Open Access This article is distributed under the terms of the Creative Commons Attribution 4.0 International License (http://creativecommons.org/licenses/by/4.0/), which permits unrestricted use, distribution, and reproduction in any medium, provided you give appropriate credit to the original author(s) and the source, provide a link to the Creative Commons license, and indicate if changes were made.

\section{References}

Bekker-Nielsen T (2010) Fishing in the Roman World. In: Bekker-Nielsen T, Bernal-Casasola D (eds) Ancient nets and fishing gear, proceedings of the international workshop on nets and fishing gear in classical antiquity: a first approach. Aarhus University Press, Aarhus, pp 187-204

Boetto G (2010) Fishing vessels in Antiquity: the archaeological evidence from Ostia. In: BekkerNielsen T, Bernal-Casasola D (eds) Ancient nets and fishing gear, proceedings of the international workshop on nets and fishing gear in classical antiquity: a first approach. Aarhus University Press, Aarhus, pp 243-256

Camardo D (2008) Lo scavo della fogna dell'Insula Orientalis II. In Guzzo PG, Guidobaldi MP (eds) Nuove ricerche archeologiche nell'area Vesuviana (scavi 2003-2006). Atti del Convegno Internazionale, Roma, 1-3 febbraio 2007. L'erma di Bretschneider, Roma, pp 415-423

Carannante A (2008) L'ultimo garum di Pompei. Analisi archeozoologiche sui resti di pesce dalla cosiddetta "Officina del garum". Rivista di Natura Scienza e Tecnica nel Mondo Antico 3-4(1):43-55

Craig O, Bondioli L, Fattore L, Higham T, Hedges R (2013) Evaluating marine diets through radiocarbon dating and stable isotope analysis of victims of the AD79 eruption of Vesuvius. Am J Anthropol 152:345-352

De La Huz R, Lastra M, Lopez J (2002) The influence of sediment grain size on burrowing, growth and metabolism of Donax trunculus L. (Bivalvia: Donacidae). J Sea Res 47(2):85-95

Froese R, Pauly D (eds) (2000) FishBase 2000: concepts, design and data sources. ICLARM, Los Baños, p 344

Froese R, Pauly D (eds) (2018) Fishbase. World wide web electronic publication. www.fishbase.org. Accessed June 2018

Gabriel S, Fabião C, Filipe I (2009) Fish remains from the Casa do Governador-a Roman fish processing factory in Lusitania. In: Makowiecki D, Hamilton-Dyer S, Riddler I, Trzaska-Nartowsky N, Makohonienko M (eds) Środowisko i kultura vol. 7, Fishes-culture-environment through archaeoichthyology, ethnography and history. Proceedings of the 15th meeting of the ICAZ Fish Remains Working Group, September 3-9, 2009 in Poznan \& Torun, Poland. Bogucki Wydawnictwo Naukowe, Poznan, pp 117-119

Gallo L, Lucadamo L, Mezzotero A, Morisi A, Battegazzore M, Fenoglio S (2012) First data on the freshwater fish fauna of Calabria (southern Italy). Ital J Zool 79(2):246-251. https://doi. org/10.1080/11250003.2011.631943

Grainger S (2013) Roman fish sauce: fish bones residues and the practicalities of supply. Archaeofauna $22: 13-28$

Grainger S (2014) Garum, Liquamen and Muria: a new approach to the problem of definition. In: Botte E, Leitch, V (eds) Fish \& ships. production and commerce of salsamenta during antiquity. Bibliothèque d'Archéologie Méditerranéenne et Africaine 17. Centre Camille Jullian, Aix-en-Provence, pp 37-46

Green P (1974) (Trans) Juvenal. The Sixteen Satires. Penguin Books, London

Jones AKG (1986) Fish bone survival in the digestive systems of the pig, dog and man: some experiments. In: Brinkhuizen DC, Clason AT (eds) Fish and archaeology. Studies in osteometry, taphonomy seasonality and fishing methods. British Archaeological Reports Int. ser. 294. British Archaeological Reports, Oxford, pp 53-61

Kruschel, C, Zubak, I, Schultz, ST (2012) New records of the parrot fish Sparisoma cretense and the cleaver wrasse Xyrichtys novacula, by visual census in the Southern Adriatic. Ann Ser Nat Hist 22:47-51

La Valle P, Nicoletti L, Finoia MG, Ardizzone GD (2011) Donax trunculus (Bivalvia: Donacidae) as a potential biological indicator of grain-size variations in beach sediment. Ecol Ind 11:1426-1436

Lo Sarà G, Martire M, Buffa G, Mannino AM, Badalamenti F (2007) The fouling community as an indicator of fish farming impact in Mediterranean. Aquac Res 38:66-75

Locker A (1999) Fish bones. In: Fulford M, Wallace-Hadrill A (eds) Towards a history of pre-Roman Pompeii: excavations beneath the house of Amarantus (I.ix.11-12), 1995-8. Papers of the British School at Rome LXVII: 94, 138 
Lombarte A, Chic Ò, Parisibarad V, Olivella R, Piera J, García-Ladona E (2006) A web-based environment for shape analysis of fish otoliths: the AFORO database. Scientia Marina 70(1):147-152

Louisy P (2015) Europe and Mediterranean marine fish identification guide, 3rd edn. Ulmer, Paris

Martyn REV, Garnsey P, Fattore L, Petrone P, Sperduti A, Bondioli L, Craig OE (2018) Capturing Roman dietary variability in the catastrophic death assemblage at Herculaneum. J Archaeol Sci 19:1023-1029

Marzano A (2013) Harvesting the sea. The exploitation of marine resources in the Roman Mediterranean. Oxford University Press, Oxford

Mavidis M, Koukouras A, Eleftheriou A (2006) Factors affecting the distribution of the bivalve Donacilla cornea (Poli, 1795) in Eastern Mediterranean sandy beaches. J Biol Res Thessaloniki 6:187-198

Nicholson RA (1993) An investigation into the effects on fish bone of passage through the human gut: some experiments and comparisons with archaeological material. Circaea 10(1):38-51

Ørsted P (1998) Salt, fish and the sea in the Roman Empire. In: Nielsen I, Nielsen HS (eds) Meals in a social context. Aspects of the communal meal in the Hellenistic and Roman world. Aarhus University Press, Aarhus pp 13-35

Parenzan P (1970-76) Carta d'identità delle conchiglie del Mediterraneo Vols 1 and 2i-ii. Bios Taras, Taranto

Psomadakis PN, Giustino S, Vacchi M (2012) Mediterranean fish biodiversity: an updated inventory with focus on the Ligurian and Tyrrhenian seas. Zootaxa 3263:1-46

Rackham H (1983) (Trans) Pliny. Natural History. Books 8-11, 2nd edn. Loeb Classical Library, Harvard University Press, Cambridge

Reese DS (2002a) Fish: evidence from specimens, mosaics, wall paintings and Roman authors. In: Jashemski WF, Meyer FG (eds) The natural history of Pompeii. Cambridge University Press, Cambridge, pp 274-291

Reese DS (2002b) Marine invertebrates, freshwater shells, and land snails. Evidence from specimens, mosaics, wall paintings and Roman authors. In: Jashemski WF, Meyer FG (eds) The natural history of Pompeii. Cambridge University Press, Cambridge, pp 292-314

Roberts P (2013) Life and death in Pompeii and Herculaneum. The British Museum, London

Roselló-Izquierdo E (1986) Contribición al atlas osteológico de los teleósteos Ibéricos 1. Dentario y articular. Ediciones de la Universided Autónoma de Madrid, Madrid

Rowan E (2014a) Roman diet and nutrition in the Vesuvian region: A study of the bioarchaeological remains from the Cardo V sewer at Herculaneum. Unpublished $\mathrm{PhD}$ thesis, University of Oxford, Oxford

Rowan E (2014b) The fish remains from the Cardo V sewer: New insights into consumption and the fishing economy of Herculaneum. In: Botte E, Leitch V (eds) Fish and ships. Production and commerce of salsamenta during Antiquity. Bibliothèque d'Archéologie Méditerranéenne et Africaine, vol 17, pp 61-67

Rowan E (2017) Bioarchaeological preservation and non-elite diet in the Bay of Naples: an analysis of the food remains from the Cardo V sewer at the Roman site of Herculaneum. Environ Archaeol 22:318-336

Ruscillo D (2005) Reconstructing murex royal purple and Biblical blue in the Aegean. In: Bar-Yosef D (ed) Archaeomalacology: molluscs in former environments of human behaviour. Oxbow, Oxford, pp 99-106

Sabelli B, Giannuzzi-Savelli R, Bedulli D (1990-92) Catalogo annotato dei molluschi marini del Mediterraneo. Annotated check-list of Mediterranean marine molluscs, 1-3. Società Italiana di Malacologia, Bologna

Santini F, Carnevale G, Sorenson L (2014) First multi-locus timetree of seabreams and porgies (Percomorpha: Sparidae). Ital J Zool 81(1):55-71

Theodoropoulou T (2014) Salting the East: evidence for salted fish and fish products from the Aegean sea in Roman times. In: Botte E, Leitch V (eds) Fish \& ships: production et commerce des salsamenta durant l'Antiquite. Bibliothéque d'Archéologie Méditerranéenne et Africaine 17. Centre Camille Jullian, Aisen-Provence, pp 213-227

Tiberi N (1879) Le conchiglie Pompeiane. Bulletino della società malacologica italiana 5. Società Malacologica Italiana, Pisa, pp 139-151

Van Neer W, Lentacker A (1994) Fish sauce in the Northern Provinces of the Roman empire. Archaeofauna 3:53-62

Wallace-Hadrill A (2012) Herculaneum past present and future. Frances Lincoln, London

Zupo V, Stübing D (2010) Diet of fish populations in Posidonia oceanica meadows off the Island of Ischia (Gulf of Naples, Italy): assessment of spatial and seasonal variability. Nat Sci 2(11):1274-1286 